УДК: 94(477.64):629.735:329.285 «1918/1920»

DOI: 10.26661/zhv-2019-1-53-12

\title{
The aviation of the Makhno movement (1918-1920)
}

\section{Chop \\ Zaporizhia Natiolal Technical University chopvolodimir@ukr.net}

Key words: aviation, air force, aeroplane, the Makhno movement, anarchism, Berdiansk, Nestor Makhno.
The article explores the history of the air forces of the Makhno movement in a period from 1918 to 1920 during the existence of the Revolutionary Insurrectionary Army of Ukraine (the Makhnovists) and provides a short historiographical review of the existing publications on the topic. It describes the attitude of the anarchist insurgents towards the advanced technological military equipment of the beginning of the twenty-first century and its usage in warfare. It talks about constant and persistent attempts of the rebels to capture aeroplanes as trophies, their usage for their own purposes and ways to hide or destroy them in case of adverse circumstances.

The major part of the article is a narrative about the rebels' attempts to initiate mass production of the "Farman HF. 30" aeroplanes at the "Widow Mathias \& Sons" factory in Berdiansk in the spring of 1919, the characteristics of the process and general results of this activity. The number of aeroplanes produced by the factory and their distribution between the insurrectionary forces and the Ukrainian Red Air Fleet is calculated. Among other things it talks about legal problems tied to the handing of the aeroplanes to the Makhnovist 3rd Zadniprovska brigade and the 1st Ukrainian insurrectionary division. A certain part of the article is dedicated to the visit of the division commander Dybenko P. to Berdiansk tied to the problems mentioned before, the role of the "plane of anarchy" in the attack on Mariupol on March 28-29, 1919 and in the suppression of Padalko's anti-Makhnovists putsch arranged on March 31, 1919.

The author talks about different ways in which the rebels had solved the problem of the lack of aviation fuel in 1919-1920 by following a requisition practice. The article informs about the cases when the Red Army (reconnaissance air squads) was used for the benefit of the Makhnovists during their politico-military treaties with the Bolsheviks. A certain place is devoted to the description of the first flights of the insurrectionary leader Nestor Makhno. The article mentions the theme of the Makhnovists' aviation in English fiction of the latter half of the twentieth century.

\section{Авіація махновського руху (1918-1920рр.)}

\author{
B. M. Чоп \\ Запорізький національний технічний університет
}

Ключові слова: авіація, військово-повітряні сили, аероплан, махновський рух, анархізм, Бердянськ, Нестор Махно.

\begin{abstract}
В статті досліджується історія військово-повітряних сил махновского руху в період з 1918 по 1920 рік. Описується ставлення українських повстанців-анархістів до передової військової техніки початку XX століття. Розповідається про багаточисельні спроби захоплення повстанцями трофейних аеропланів та про спроби налагодити їх масове виробництво на заводі «Вдова Матіас та сини» у Бердянську. Повідомляється про використання червоної авіації на користь махновців під час їх військово-політичних союзів, а також про перші повітряні польоти керівника повстанців Нестора Махна.
\end{abstract}

Despite a large amount of documentary materials available to the researches, the history of the Makhno movement remains a scarcely explored topic in our history, even though modern Ukrainian historiography put a lot of effort into making the time of general reviews on the history of Makhnovshchyna be gone forever [1]. At the same time an array of the aspects of political and military life in the history of the insurgent movement stay unanalysed. Among them are research works on the 
Insurrectionary Army's armed forces and armament, on air forces of the Makhno movement in particular.

The topic of the Makhnovists' aviation had been completely unexplored till 2008, when the author published an article on this matter in a historical periodical "Expedition-XXI" ("Ekspedytsiia-XXI") $[2 ; p .8]$. The publication caused some resonance, it served as a base for a publication of Snegirev V. [3; p.18] and an article "Revolutionary Insurrectionary Army of Ukraine Air Fleet" in a Russian segment of Wikipedia. The presence of public interest in this topic encouraged the author to make an expanded publication in form of a separate chapter in a monography "Free Berdiansk" ("Volnyi Berdiansk") [4; p.97]. Some additional help to the author was provided by the publications of historians Khairulin $M$. $[5 ; p .147]$ and Kharuk A. $[6 ; p .28]$ that have been published in recent years.

The first time the Makhnovists obtained planes was on December 29, 1918 when Makhno N. captured Katerynoslav in alliance with the Bolsheviks. Seven reconnaissance "Nieuport-23" aeroplanes were taken at the town airfield nearby Feodosia barracks. These planes from the 8th air division had been standing there even since February 1917, moving from one conqueror's hands to the other's. And now planes, for a short period of time, ended up in Batko Makhno's possession. In fact war trophies were the actual reason he got involved in a risky attempt to take over a large town. But the rebels did not manage to transport the trophies, a disassembled aeroplane in particular. First an odd railway accident happened to Makhno's echelon, and then an unexpected counter-attack of the Republic troops took place. On December 31, 1918 the Makhnovists had to hastily leave the town and planes.

Nevertheless the dream of Makhno N. to get up in the air on an aeroplane was postponed only for a short time. On January 26, 1919 the treaty of alliance between the communists and the rebels was renewed, this time on a higher level. One of the conditions of the treaty was to provide the Makhnovists with all technological means that were at the Ukrainian Front's disposal. After recapturing their capital, the village of Huliaipole, from the Denikins on January 27, 1919 [7; p.34], the Makhnovists, despite the conditions of late winter, built an airfield in the outskirts of the village.

On February 3, 1919 People's Military Commissar of the USSR Mezhlauk V., issued a decree No.8 about the establishment of the Office of Ukrainian Red Army Air Fleet (URAAF) consisting of four reconnaissance air divisions (RAD). It was the URAAF that Makhnovists' aeroplanes formally belonged to during March-June 1919. We are especially interested in the 22nd RAD that initially was based in Orel, but in the end of January 1919 was transferred to Ukraine. Dybenko P. managed to wangle it for his division from the high command of the front. It was with the help of aviation that Dybenko P. wanted to seize Perekop and push ahead through Sivash. But, while the 1st Zadniprovska division was moving towards the Crimean isthmus, Makhno, during his meeting with Dybenko P. on February 12, 1919 at the "Polohy" station, managed to temporally wangle two aeroplanes to be in his disposal to help him launch an offensive towards the Sea of Azov coast.

At the beginning of March 1919 two planes from the 22nd RAD arrived to Huliaipole. They were "Sopwith 1 Strutter" aeroplanes of English design, two-seater multifunctional biplanes with tractor configuration that in aviation jargon were just simply called "Strutters". The "Strutter" was armed with two machine-guns and was able to carry up to 100 $\mathrm{kg}$ of air bombs. The engine would boost a plane to a speed of $160 \mathrm{mph}$. Military aviators Ionin and Bulgakov arrived to provide assistance to the Makhno's offence. Their flight reports were preserved in Russian Military State Archive's collections (Ф. 936). For example on March 7, 1919 at 9:30 a.m. pilots took the cargo of six 25-pound bombs and flew out to scout the route Huliaipole - Tsarekonstantynivka - Velykyi Tokmak - Orikhiv.

In Tsarekonstantynivka that at the time was under the Whites' rule pilots performed a bombing of station buildings from the height of $1,100 \mathrm{~m}$. Though in truth they did not make it all the way to Orikhiv, turning and heading back to the base right after Tokmak. A strong headwind at the height of $1,800 \mathrm{~m}$ caused an over-expenditure of petrol and frozen pilots returned to Huliaipole at 11:25 for their report. On the same day the pilot Ionin sent a telegram to Katerynoslav to the division headquarters. He was resentful and was wondering why his combat cargo had not been shipped to Huliaipole yet, demanding for it to arrive by the following morning, March 8 . Without bombs and spare parts the pilot was threatening to quit scouting [8; Спр.13. - Арк.80.]. The next day he was giving Batko Makhno a ride above Huliaipole. Flying on the aeroplanes from the 22nd RAD was a high-risk engagement. Because of the severe mechanism wear, low-quality petrol and low qualification of the pilots planes frequently crashed. Thus on January 30, 1919 an accident involving an aeroplane from the 22nd RAD occurred in Katerynoslav, where division commander Dybenko P. was giving a parade after capturing the town. Initially the aeroplane was flying above the marching regiments 
but then, during an attempt to land on a town square, it turned upside down in the midair and beheaded two cavalrymen with its propeller. "The aviator himself, half-alive and covered in blood, was dragged from under the airplane wreckage" - wrote a witness of those events [9; p.88].

So, on March 7, 1919 the pilot Ionin seated Makhno N. in the back cockpit of the "Sopwith" and gave Batko a tour above Huliaipole, an entry about which stayed in a flight journal [6; p.149]. A fully fueled "Strutter" was able to fly for three hours, but Makhno's flight only lasted 10 minutes because of the acute shortage of the second-class petrol that the aeroplane was fueled with. It was then that the majority of Huliaipole citizens and rebels saw an aeroplane for the first time in their lives. In neighboring Berdiansk local townsmen have seen Utotschkin S. fly at the fair back in 1910 [10; p.11.], but to Huliaipole the first aeroplane was brought by war.

By the way, what was painted on the sides of those "Sopwithes" as individual identification symbols? According to the intelligence of Khairulin $\mathrm{M}$. the conscience of the RKKA military aviators allowed them to pain black stars on crimson background, half naked and naked woman, frogs, caricature demons, skeletons holding scythes in their hands and also images of a dead head accompanied by bones on their aeroplanes. Moreover the Makhnovists used latter two symbols on their flags in the spring of 1919 [6; p.256].

In general the Makhnovist command was satisfied with the aviators and was not against having a personal aeroplane. The rebels even knew where to get one. On March 15, 1919 they managed to seize Berdiansk. A Franco-Belgian joint-stock company back in 1914 had already customized part of the production facilities of the "Widow Mathias \& Sons" mechanical factory so it was able to produce aeroplanes. In 1917 the workers of the seaside town managed to start a production of two types of aeroplanes: a heavy "Farman HF.30" and a light reconnaissance aeroplane "Anasal". Unfortunately for the Makhnovists the production facilities of the factory had already been severely damaged, but there was some produce left.

In the "Mathias" factory storehouse the rebels discovered the remains of 5 "Farman HF.30" planes. The Whites did not have an opportunity to carry planes out of the town when they were fleeing Berdiansk on steamboats, so they have just damaged them. But not as much as to make it impossible to put together a working plane out of five broken ones. On March 17, 1919 in a telegram to the division headquarters the brigade commander Makhno N. was asking to send out to Berdiansk air-fitters and pilots that would start repairing planes and receive spare parts sent from the north [8; Спр.13. Арк.6]. The Makhnovists were going to look for air-fitters at the Aleksandrivsk factory "Deka". The specialists have been found and everything was done in a week.

Berdyansk "Farman HF.30" aeroplanes that were destined to become the first "planes of anarchy" were named after French aircraft designers, brothers Henry and Maurice Farman. They had been being assembled under a license at Russian Empire aircraft factories since 1916 . The specialists considered "Farman HF.30" a cheap and reliable plane, though already outdated. In everyday language "Farman HF.30" was often referred to as "Farsal". But it was the very same "Farman HF.30", or, as it was also called, an "apron" ("fartukh") or a "thirty" ("trydtsiatka"). The "Salmson" 150 horsepower engine gave the plane an ability to speed up to 136 $\mathrm{km} / \mathrm{h}$ and rise to the height of $3,000 \mathrm{~m}$ [11; p.312].

"Farman HF.30" was a single-engined biplane of a pusher configuration without fuselage. Between his wings a two-seat open cockpit was situated. The plane had bad maneuverability and low speed that made it an easy prey for fighter planes. But it was possible to disregard these circumstances because of the almost complete absence of the Whites' aeroplanes on the Makhnovists' front. The last time the Makhnovists saw an enemy plane was on March 2, 1919 in the outskirts of Melitopol. Besides, in the spring of 1919 the Whites often just did not bother their rivals, hoping that the latter will take their side. The end to such aero humanism would come only in the autumn of 1919. The RKKA used "Farman HF.30" as a reconnaissance plane till 1921 and as a training plane till 1925. The last time the RKKA used it in combat circumstances was in the Chechen mountains during the suppression of an anticommunist rebellion in 1925 [12; p.34].

Though in truth two complications emerged with the Makhnovists using the "plane of anarchy". Firstly, the fuel issue needed to be solved. The rebels were well aware that they should not expect their allies Bolsheviks to supply it. As a matter of fact, the actual reason why the Bolsheviks overlooked Makhno's attempts to build an air force was because they did not believe that Makhno would be able to somehow solve the problem with the fuel. In their opinion Berdiansk "Farsals" were, at most, only good to sooth his ego.

The Reds were hoping that the Makhnovists will fill their aeroplanes with field-proven "Kazan mixture", an aviation gasoline surrogate. All avgas of the Russian Empire was supplied from near 
Baku that at the time was outside the front area, so the only option was to fly on surrogates. The "Kazan mixture" consisted of kerosene, gasoline, ethanol and ether, sometimes with the addition of second-class petrol. It was true that the Makhnovists had nowhere to take gasoline from, but it was possible to fill the plane with "aviation cognac". It was the name of various ethanol and methanol mixtures that one could fill rotary aircraft engines with. The "Salmson" engine was so well designed that it was able to work on cognac spirit of a decent quality. Azov wine dealers that had not had a sales market since 1914 started to turn wine material into cognac spirit using distillatory vessels. The distillation method, fractionation and maturing in barrels led to quite good results. The barrels were being stocked in Berdiansk and Mariupol as well as in villages. A popular around Berdiansk variety of vine called "Berizka" (Chasselas) provided splendid cognac spirit. Though diethyl ether needed to be added to the aviation cognac at winter, but the winter was still a long way off. The aviation cognac was unpopular with military aviators because it could not be used in front engine aeroplanes. Pilots would poison themselves with spirits' combustion products due to a bad hermetic encapsulation of engine compartment hoods. The "Farsals" were of a pusher configuration and their pilots were not risking to suffocate during a flight. The only had to find ethanol and confiscate it from its owners.

On March 29, 1919 Batko Makhno's personal No.1 order was put on walls throughout Berdiansk, "All doctors, drug stores and civilians are to immediately hand over all available ethanol reserves to Makhno's headquarters. Those found guilty of disobedience will be punished" [4; p.73]. Later on the communists, trying all possible ways, were dropping hints that the rebels were trying to store up ethanol for their benders and orgies with this order. But this was an evident propaganda version. In their benders the Makhnovists were getting along just fine with ordinary wine. The ethanol was needed as an antiseptic and to lift the "plane of anarchy" into the air. When later the Berdiansk Revolutionary Committee started an anti-alcohol campaign, destroying the reserves of wine and cognac spirit, it was not done to just prevent alcoholism, but also to sabotage the Makhnovists' aviation project. Secretary of the Revolutionary Committee Fistov D. recalled that in AprilMay, 1919 the members of the Committee destroyed 80,000 buckets of wine [4; p.78]. Similar situation could be observed later in Mariupol. Secretary of the County Committee Horokhov L. reported to the CC $\mathrm{CP}(\mathrm{b}) \mathrm{U}$ on May 14, 1919, "The Revolutionary Commit- tee is being daily showered in requests of different articles, among them the main spot belongs to ethanol" [13; Спр.17. - Арк.4.].

Secondly, according to the RKKA structure only a division was allowed to have a subordinate air squadron, and the armed forces of the Makhno movement only formed one brigade, though in numbers it was close to a division. Because of that, following the protocol, the plane should have been placed at the disposal of Dybenko P.

But at that point political motives came forward. From the very beginning the Makhnovists were not a common, standard brigade within the RKKA. They were political allies of the CPSU(b), and Batko Makhno was the most famous insurrectionary ataman of Ukraine, whose moderate allegiance to the Soviet rule was worth a lot. That is why his objective requests had to be reckoned with. Therefore the division commander Dybenko P., as agreed upon with the high command, decided to give the plane to Makhno N. as a gift. Not as much to appease the ally but as to make him lower his guard, because it was planned to commit an attempt upon the life of Batko during the visit, removing him from the political map of Ukraine. After that the plane could just be taken back if wished so.

Later Arshynov P. recalled, "Makhno had been repeatedly receiving warnings - by no circumstances to appear when summoned neither to Katerynoslav nor to Kharkiv, because every official summons would mean a death trap" [14; p.79]. And so in the end of March 1919 Dybenko P. summoned him to the division headquarters to Katerynoslav to report. of course Makhno did not go anywhere, saying that he was too busy advancing on Mariupol and made an arrangement that Dybenko will come to him himself. After that, on March 28, 1919 Makhno N. told his trusted people that Dybenko P. was coming to Berdiansk to kill him. The division commander arrived late at night. Despite that a meeting was organized where the plane's handover to the Makhnovists was announced. After the meeting grateful Makhno N. asked Dybenko P. to follow him to the headquarters.

Makhno N. had entered the room, in the presence of a few commanders he stated that the communists wanted to kill him with the involvement of Dybenko P. In circumstances like this Makhno, always ready to act, could easily kill the commander. The division commander started to deny the charges and asked Makhno N. to accompany him to a different room for a private conversation. That is when, saving his life, Dybenko P. gave away to Makhno N. a secret plan to eliminate the insurrectionary elite with the 
help of the commander of the 3rd brigade of the Pokrovsk regiment Andrii Padalko.

Actually it was a backup plan in case Dybenko P. fails to deal with Makhno N. on his own. Then, when Makhnovists' major executives would be going back home to Huliaipole from Pryazovia, the regiment of Padalko A. should attack the "Huliaipole" station from the north and there, in the echelon, arrest Makhno's headquarters personnel to later hand them to the revolutionary tribunal. After what he had heard Makhno N. waited till Dybenko P. left Berdiansk and immediately after that rushed to the airfield where the plane had already been waiting for him. On March 31, 1919 he arrived to Huliaipole. Arshynov P. wrote on this subject, "The conspiracy was exposed by Makhno himself when he was in Berdiansk ... It was prevented only because Makhno had an aeroplane at hand on which he managed to cross the distance between Berdiansk and Huliaipole in a little more than two hours" [14; p.130.]. Makhno N. landed on an airfield where he met with the squad of loyal Skomskyi F. Together they launched a sudden attack on camp of Padalko's people. The organizers of the conspiracy were arrested and shot immediately [7; p.38.]. "A Petrograd bolshevik Tsykov M." [15; p.40] that served as a commissar under Padalko A. was also killed near Huliaipole along with Padalko A.

However, the Makhnovists had begun to use the plane even before the official handover ceremony. The plane participated in capturing Mariupol on March 28-29, 1919. Battles for Mariupol had big strategic meaning, with its capture the White Crimea would have been completely separated from the White Don. The town was protected by two French destroyers. Aside from the White Guardsmen the French interventionists and Czechoslovak legionnaires were also there. The Makhnovists were backed-up by the "Spartak" armored train and the "plane of anarchy" as a last trump card. The latter conducted air reconnaissance and bombing of the port territory where the enemy's artillery was concentrated. The town and the Mariupol port were taken by storm in the course of a day.

From May 13, 1919 onwards the "plane of anarchy" was assigned to the 2nd brigade of the Ukrainian insurrectionary division [16; p.187]. The armed forces of the Makhno movement grew from brigade to a division in the beginning of May 1919. It was in a direct disposal of the commander of the UID 2nd brigade Viktor Bilash.

The workers and the Makhnovists of Berdiansk did not stop at building the first "plane of anarchy". Quite soon all 5 "Farsals" damaged by the Denikins were restored. Unbelievably, but among the general ruin they managed to restore the production facilities and initiated mass production of aeroplanes. In April 1919 an additional treaty between the Makhnovists and the USSR was signed about the terms of the manufacture of industrial produce in the region controlled by the rebels. In exchange for technical and material support the Makhnovists agreed to hand not only the echelons with Donetsk coal or bread, but also a certain amount of aeroplanes produced at the "Mathias" factory to the RKKA. Kharchuk A. notes that "one Berdiansk aeroplane from the "Mathias" factory had arrived to Kiev to the Post-Volynskyi airfield in the end of April 1919, on May 10 it was put to test and included in the UMAF 48th reconnaissance air squadron. In the end of May another 5 "Farsals" arrived to the squadron from Berdiansk (serial Nos. 8, 15, 16, 17 and 20) [6; p.29]. Proceeding from this data and also from the fact that at the "Mathias" factory they had kept products sequentially numbered since 1917 the following picture is being created. The "Farsals" numbered from 1 to 5 were made in the autumn of 1917 and delivered to the Russian army. The No.6 "Farsal" became the first "plane of anarchy". No.7 was given away to the Reds in the end of April 1919 , only because there happened to be a direct threat of the Whites occupying Berdiansk due to the breakthrough of the Shkuro's cavalry. Nos. 8, 9, 10, 11, 12, 13, 14, 18 and 19 "Farsals" stayed with the Makhnovists. Planes Nos. 15, 16, 17 and 20 were handed to the UMAF in the end of May 1919 when the threat of the Denikins taking over Berdiansk appeared again. Thus in the end of May 1919 the 1st Ukrainian insurrectionary division accumulated 10 planes in its possession. It was enough to form two division air squads. Makhno's ambitions were quite large-scale, in May 1919 the rebels wished to form an "army of the Makhnovists rebels", and an army needs a respective number of aeroplanes.

One of these planes was moved to Huliaipole in the end of May 1919 and was used by the division commander Makhno N. to carry out front flybys. His wife, a teacher from Huliaipole, Kuzmenko $\mathrm{H}$. recalled that the aeroplane, along with the automobile "were sent from the Red Army headquarters"; this means that the permission to do so was formally given by the 2 nd Red Army headquarters situated in Aleksandrivsk. Also "mother Halina" could not be mistaken in the fact that Makhno N. had took her to fly along with him [17; p.357]. Though the Makhnovists" "Farsals" did not fly for a long time, because it was hard to fill planes whose engines were consuming $640 \mathrm{~kg}$ of ethanol every 20 hours of work. 
By the way, why weren't the leaders of Makhnovshchyna boasting with their aviation achievements? The answer is simple, "Makhno's aviation" was foolishly lost in the summer of 1919 during a retreat from Berdiansk. It's one thing to initiate plane manufacture, and a completely different one to preserve the planes for a long-term military use. The planes were left for the enemy right on the lots near the factory, because the rail connection with Berdiansk was cut prior to the retreat. Kharuk A. notes that "after the Whites took Berdiansk in summer (of $1919 p-$ V.CH.), they were repairing the planes of the Armed Forces of South Russia at the factory ("Mathias" - V.CH.)". Among them were the "Farsals" simply damaged by the Berdiansk workers, because there was no need to repair new British and French aeroplanes that were delivered by the White Guardsmen via the Berdiansk port.

A new attempt to lift a rebel plane up into the air was made in the autumn of 1919. In the summer of 1919 the Denikins organized a military property storage on the territory of the "Varshavskyi Arsenal" factory in Berdiansk. During the Berdiansk assault by the Makhnovists on October 13, 1919 the artillery fired at this storage facility and ammunition detonated. The explosion buried the remains of the White military equipment, including several "Nieuport" aeroplanes at the Berdiansk near foreland. Afterwards the Makhnovists started to count the survived trophies: 2,000 shells, 26 English and Russian cannons, 3,000,000 bullets, 50 machine guns, 5 armored cars and, finally, the survived aeroplane, the news about which were gladly announced in the Makhnovists' newspaper "Put K Svobode" ("Road to Freedom") [18; p.1]. Kubanin M. writes about a surviving, and what is more, a properly functional aeroplane in his book [19; p.115]. It was a "Nieuport-23" biplane. The pilot for the plane had not been found and it never took off into the sky right till the moment when they were forced to again give Berdiansk away to the enemy. After burning the plane the Makhnovists left town on November 4, 1919.

The next meeting between the aviation and the Makhnovists happened in half a year, when the Red aviation began to bomb the rebels and shoot their cavalry with machine guns [20; p.28], so the latter began to slaughter sleepy "red falcons" at nights in an act of revenge. If the high command was not there in time the rebels would take the skin and wires off the aeroplanes, and then blow them up with dynamite or burn the machine's frame.

The military aviator Viechfinskii 0 . talked about how in Kharkivshchyna (Kharkiv region) in Au- gust of 1920 a special air squadron consisting of two "Farmans" was formed to chase the shunting group of the $\operatorname{RIAU}(\mathrm{m})$. “...Unbelievable mobility of the gang, its 60-90 verst marches made in the course of a day, the demands (of the high command - V.CH.) to constantly change the location of the squad's camp; this was especially hard in regard to the search of air fields. Besides, operation centers did not have permanent or precise locations that also made pilots' work more difficult and jeopardized their flights in cases when they needed to perform an emergency landing. The latter fact even had tragic consequences, one of the squad's planes whose pilots did not have accurate orienting points for their location and bandits' pursuit were captured by them and brutally killed during an emergency landing" $[21 ;$ p.58]. Nevertheless the Makhnovists did not break the "Farman" itself. Over the course of a week it was transferred disassembled via the supply-chain. For the last time it was noticed in Starobilsk on September 3, 1920. [22; Спр.26. Арк.190]. The Makhnovists did not take the "Farman" on their raid on Don, stashing it away in one of their famous hiding places in Izium forests.

After the new treaty with the Bolsheviks in the autumn of 1920 and the relocation of the $\operatorname{RIAU}(\mathrm{m})$ to Wrangel's front in October 1920 the absence of an aviation of their own clearly began to worry the Makhnovists' high command. Both their enemies and allies already had dozens of planes under their command. As of October 1920 at the South Front the Reds had 84 planes, the Whites had more than 40 and it was worrying the Makhnovists because the enemies were actively using aeroplanes against cavalry. Thus, in June 192011 "De Havilland" aeroplanes throwing bombs and firing machine guns helped the Whites to smite the horse corps of Zhloba D. near Melitopol [16; p.419], when more than 1,000 Red Army soldiers had died and 9,000 were taken captive.

The Makhnovists got their share from the enemy aviation as well. On October 25, 1920 the forces of the 2 nd Cossack division of Morozov V., which had 4 aeroplanes in its ranks, did not let the Makhnovists of the south to take Huliaipole. The Makhnovists solved the problem committing the night assault on the village on October 26 when it was impossible to use aviation against them $[16 ; p .468]$. But after this incident the necessity of capturing at least one plane for air reconnaissance became clear to everybody.

An aeroplane could be taken from the Reds. Thus the military aviator Anoshchenko N. recalled that in October 1920 the 9th squad of the 51st division 
on its way from Kakhovka to Perekop was assaulted by Batko Makhno a couple of times. And since at the time the Reds and the Makhnovists were on the same side the Makhnovists, of course, wanted not to damage the allies' planes, but to keep them for themselves. But the best solution was to capture military trophies.

Towards evening on October 29, 1920 the special Crimean group of the RIAU(m) under Karetnikov S. command fought and seized Melitopol taking big trophies from the White Guardsmen, such as: 100 cars of ammunition, 3 armored trains, 2 tanks, 18 cannons and 4 aeroplanes [16; p.419]. They were the very same enemy "De Havillands D.H.5" that were pursuing them near Huliaipole two days before that. One-seat fighters made of wood and linen by the British constructor Geoffrey de Havilland could boost to the incredible speed of $164 \mathrm{~km} / \mathrm{h}$ and rise as high as $4.5 \mathrm{~km}$. Although in Britain this aeroplane had been out of production as outdated since the autumn of 1918, it were the "De Havillands" that became the main strike force of the Russian Army aviation in 1920. Surely the aeroplanes needed repair and, again, pilots, but in accordance with the "gentleman's agreement" between the Makhnovists' high command and the Reds, all trophies captured by the Makhnovists were considered an Insurrectionary Army's property. Though admittedly they needed to be guarded, especially after the headquarters of the Southern Front under the command of Frunze M. moved to Melitopol. After almost a month of demurrage on November 26, 1920, right after the announcement that outlawed the Makhnovists, the planes in Melitopol were seized by the squad of red cadets.

But before this unfortunate incident there the Makhnovists' breakthrough to the White Crimea took place where the Crimean group, among other things, continued its hunt for enemy's aviation property. Thus at the "Voinka" station the Makhnovists had almost seized "a perfectly equipped aviation manufactory on wheels" [23; p.522]. Retreating the White Guardsmen set fire to forage cars that were standing nearby and the manufactory located in the railroad cars burned along with them.

On November 14, 1920 the Makhnovists, running ahead of the RKKA troops, burst into Simferopol. Here, on the territory of an aircraft depot and a Simferopol affiliate of the "Anatra" aviation factory they captured a few more disabled planes. It was one "De Havilland", "Anatra DS", modifications of 1916 and also a disabled agricultural "Voisin-V" biplane, all that was left of the White movement's aviation. Ironically this captured junk became the last page in the history of the Makhno's aviation. Although the Makhnovists did not think this way at first. In Simferopol the Makhnovists' garrison was situated next to the red one. The cultural-enlightment department of the RIAU MRC (Military Revolutionary Council) was present in town and the Makhnovists were giving away their leaflets about the possibility of creating a "free Crimean republic" on the streets [24; p.62]. But on November 26, 1920 the Makhnovists' troops in town were treacherously attacked by the Reds and during their following reverse breakthrough from Crimea nobody even though about evacuating the aeroplanes.

In the following 1921 The Makhnovists attacked the locations of the red air squads, and not just once or twice, as for example in January 1921 it happened at the "Fedorivka" junction station [21; p.59], but this time it was not to capture the aeroplanes. Then began an absolute partisan war and the retreat of the remaining Makhnovists to Romania. With such circumstances planes stopped to be the Makhnovists' top priority. And they were not a second one from the top either.

The times of the "planes of anarchy" became the thing of the past only to come back to us on the pages of the alternative history novels. The case in point is a book by the English writer Moorcock M., "Steel tsar" (1971). The famous writer describes an alternative reality where the October Revolution of 1917 never happened, instead an airship industry experienced an extreme rise. In 1941 the Makhnovists' air fleet consisted of captured from the enemy and repainted in black airships. The anarchists under the command of Makhno N. join the rebels on their aircrafts armed with torpedoes and bombs and take Katerynoslav by storm together [25; p.555], in some ways repeating the events of the end of 1918 from our reality. In general the image of Makhno N. in English fiction is very peculiar [26; p.229].

In a conclusion let us note that Russian communists and White Guardsmen were in different ways trying to impose an idea to the society that the Makhnovists were always avoiding the use of military equipment because of their primitivism and lack of education. It was part of the tactic of the enemy's "image depreciation" in the information warfare. A histrionic bandit, maniac Makhno and his gang clearly were not capable of using high technology equipment. In reality neither Makhno $\mathrm{N}$., nor other leaders of the movement were ever against using technological tools. When the RI$\mathrm{AU}(\mathrm{m})$ was in its "partisan" state the lack of its machinery uniformity could be observed only through its maladjustment to fast movement, bulkiness, 
absence of permanent equipment and repair bases. Besides, mobile technological equipment and tools always were successfully used, especially artillery and machine guns. In its regular state the $\operatorname{RIAU}(\mathrm{m})$ had various heavy technological equipment: armed trains and flatcars, armed automobiles, river and sea cutters, motorcycles and, finally, aeroplanes.
Understanding the necessity of an adequate technical support for the forces Makhno's rebels tried to systematically develop their aviation both by capturing planes as trophies and by initiating the production of their own aeroplanes that were used for bombing and reconnaissance.

\section{Джерела та література}

1. Архієрейський Д. Махновська веремія. Тернистий шлях РПАУ/м/. Київ: Темпора. 2015. 340 р.; Савченко В.А. Махновська Трудова федерація (1917-1921 рр.). Харків: Фоліо, 2018. 298 р.; Чоп В.М., Лиман I.I. Нащадки запорожців: Махновський рух в Північному Празов'ї (1918-1921рр.). Мелітополь, 2019. 609 р.; Шубин А.В. Махно и его время. Москва: ЛЕНАНД, 2016. 320 р.

2. Чоп В.Н. Авиация Махно. Експедиция XXI. 2008. № 10. Р.8-9.

3. Снегирьов В. На крыльях анархии. Корреспондент. 2014. № 27. 11 июля.

4. Чоп В.М., Лиман I.I. «Вольный Бердянск»: місто в період анархістського соціального експерименту (1918-1921 роки). Запоріжжя: РА «Тандем-У», 2008. 479 р.

5. Хайрулин М. Военлёты погибшей империи. Москва: Яуза-Эксмо, 2008. 475 p.

6. Харук А. Адаменко, Матиас и другие... Малоизвестные страницы истории отечественной авиапромышленности. Авиация и время. 2006. № 6. Р. 28-29.

7. Чоп В.Н. Нестор Иванович Махно. Запорожье: Тандем - У, 1998. 84 с.

8. Матеріали 22-го розвідувального авіаційного загону. РДВА. (Російський Державний Військовий Архів). Ф. 936. 0п. 3. Спр. 13.

9. Арбатов 3. Ю. Екатеринослав 1917 - 1922. Архив русской революции. Берлин. 1922. Т.12. Р. 83-148.

10. Можаровский Г.М. Пока бьется сердце. Москва: Воениздат, 1973. 133 р.

11. Шавров В.Б. История конструкций самолетов в СССР до 1938 р. - Москва: Машиностроение, 1978. 738 p.

12. Куликов В. Фарманы в России. Мир авиации. 1993. № 4. Р.32 - 38.

13. Матеріали Всеукраїнського Центрального Виконавчого комітету. ЦДАВО України (Центр. держ. арх. вищ. орг. влади та упр. України). Ф.1. Оп.1. Спр.17.

14. Аршинов П. История махновского движения (1918-1921 гг.). - Берлин: Изд. «Группы русских анархистов в Германии», 1923. $248 \mathrm{p}$.

15. Балковий П.М. Війна без флангів. Київ: Наукова думка, 1966. 312 р.

16. Белаш А.В., Белаш В.Ф. Дороги Нестора Махно: Историческое повествование. Киев: РВЦ «Проза», 1993. 592 р.

17. Яланський В., Верьовка Л. Нестор і Галина. Розповідають фотокартки. Київ-Гуляйполе: Вид. журналу «Ярмарок», 1999. $544 \mathrm{p}$.

18. Путь к свободе. Орган ВРС РПАУ(м). 1919. 16 октября.

19. Кубанин М. Махновщина. Ленинград: Прибой, 1926. 206 р.

20. Павлов М. Значение авиации в борьбе с бандитизмом. Революционный фронт. 1920. № 9. Р. 27-29.

21. Вечфинский А. Авиация в борьбе с бандитизмом. Революционная армия. Ежемесячный орган РВС и политупра ХВ0. 1921. №1. Р.55-59.

22. Матеріали Донецького губернського виконавчого комітету (1919-1926). ДАДО (Держ. арх. Донецької обл.). Ф.Р.1146. 0п.2. Спр.26.

23. Нестор Махно. Крестьянское движение на Украине. 1918-1921: Док. и мат. / под. ред. В.Данилова. Москва: РОССПЭН, 2006. $917 \mathrm{p}$.

24. Качелин М. Дальний костер. Москва: Воениздат, 1967. 216 р.

25. Муркок М. Стальной царь. Кочевники времени. СПб.: Северо-Запад, 1994. Р. 429-604.

26. Чоп В.М. Образ Нестора Махна в творах англійських письменників-фантастів. Державна етнонаціональна політика. Збірник наукових праць VI Всеукраїнської науково-практичної конференції 6-8 жовтня 2005 р. Запоріжжя: 3НTY, 2005. P.224-229. 